\title{
Exploiting Regio-centric Product Advantage to Increase Small and Medium Enterprises' (SMEs) Marketing Performance
}

\author{
Dr. Ahmad Hanfan ${ }^{1}$, Dr. Ahmad Ikhwan Setiawan ${ }^{2}$
}

\begin{abstract}
:
This research aims to examine the role of regiocentric product advantage to improve SMEs marketing performance.

The concept of regiocentric product advantage is proposed in this study as a variable that plays an important role in improving marketing performance. The research is also conducted because of the business phenomenon that is the decrease in the number of entrepreneurs and the number of workers in salted egg industry Brebes District, Central Java Province, Indonesia.
\end{abstract}

The study has developed four hypotheses using data collected from 118 respondents of salted egg SMEs companies.

The statistical analysis processed with AMOS 22 concludes that the research hypotheses are accepted. That is the product development capability with regiocentric product advantage, the regiocentric product image capability with regiocentric product advantage, the customer sensing quality with regiocentric product advantage and the regiocentric product advantage with marketing performance are correlated.

Keywords: Theory of resource based view (RBV), regiocentric product advantage, product development capability, regiocentric product image capability, customer sensing quality, marketing performance.

\footnotetext{
${ }^{1}$ Lecturer, Department of Management, Faculty of Economics and Business, Pancasakti University, Tegal, Indonesia. Email : ahmadhanfan@yahoo.com

${ }^{2}$ Lecturer, Department of Management, Faculty of Economics and Business, Sebelas Maret University, Surakarta, Indonesia.Email : aikhwansse@yahoo.com
} 


\section{Introduction}

Product development program in a company is a program that requires a high cost, but usually the success rate in entering the market is small, so the chances of success are also small. This raises the question of what should be done to enhance the success rate of new product development (Ferdinand and Batu, 2013). The perspective on company capability began with Edith Penrose in 1959 in his book „The Theory of the Growth of the Firm” (Foss, 1999). Capability is defined as a reflection of a company's ability to organize, manage and coordinate activities (Dosi and Teece, 1998). Vesalainen and Hakala (2014) use the term corporate capabilities as a concept for organizational attributes. Company capability is a product (functional) capability coordinated by business processes and integrates other managerial activities.

Capability is a process based on information, can be tangible or intangible that is typical in the company, as a result of long-term development through a complex interaction process of various resources (Amit and Schoemaker, 1993). Ferdinand, (2003) conveyed that capability consists of know-how, raw material perception, customer service perception, ability to manage change, ability to innovate, ability to learn, ability to work group and so on. Organizational capability is one of the potential sources of competitive advantage (Bharadwaj et al., 1993; Barney, 1996). In addition, companies with a high level of organizational capability can increase the pace of launching new products to market (Zander and Kogut, 1995).

Capability-based theories show that companies are a combination of resources and capabilities, and they must continue to invest in a unique way to maintain and expand their marketing capabilities. Companies with high marketing capabilities will be pioneers in identifying customer needs and recognizing factors that affect their buying behavior will be able to put their products in the best position compared to their competitors. The ability of product development from the company has a positive effect on marketing performance (Azizi et al., 2009).

There are five dimensions of product development capability namely product quality, product cost, product development time, product development cost and product development capability. While the definition of product development capability is the company's ability to perform a series of activities starting from the perception of market opportunities and ending with production, sales and delivery of products (Ulrich and Eppinger, 2004). This research is conducted because of the research gap in the literature, that is the different results regarding the influence of product development capability on marketing performance (Table 1). 
Table 1. Differences in Product Development Capability Research Results on Marketing Performance

\begin{tabular}{|c|c|c|}
\hline Researchers & Model & Findings \\
\hline Dutta (1999) & $\begin{array}{l}\text { Dutta (1999) describes the model in his research that is } \\
\text { the ability of a company that consists of marketing } \\
\text { capability (ability to develop product) and R \& D } \\
\text { capability influence to marketing performance mediated } \\
\text { by demand-side effect. Then R \& D capability and } \\
\text { operations capability have an effect on marketing } \\
\text { performance mediated by supply side effect. }\end{array}$ & $\begin{array}{l}\text { High company product } \\
\text { development capability } \\
\text { proved to have } \\
\text { maximum impact on } \\
\text { marketing performance. }\end{array}$ \\
\hline $\begin{array}{l}\text { Baker and } \\
\text { Sinkula } \\
(2005)\end{array}$ & $\begin{array}{l}\text { Baker and Sinkula (2005) describe the model in his } \\
\text { research that enviropreneurial marketing is influenced by } \\
\text { the environment as an opportunity, the environment as a } \\
\text { commitment and the environment as the truth affect the } \\
\text { market share change through the success of new } \\
\text { products. Then market turbulence affects } \\
\text { enviropreneurial marketing, new product success and } \\
\text { market share change. }\end{array}$ & $\begin{array}{l}\text { Product development } \\
\text { capability is directly } \\
\text { influenced } \\
\text { enviropreneurial } \\
\text { marketing and has a } \\
\text { positive effect on } \\
\text { marketing performance. }\end{array}$ \\
\hline $\begin{array}{l}\text { Hoonsopon } \\
\text { and } \\
\text { Ruenrom } \\
(2012)\end{array}$ & $\begin{array}{l}\text { Hoonsopon and Ruenrom (2012) describe the model in } \\
\text { their research that is organizational culture (vision and } \\
\text { top management support) have a positive impact on } \\
\text { radical product innovation and incremental product } \\
\text { innovation. The organizational structure (centralization } \\
\text { and formalization) has a positive impact on radical } \\
\text { product innovation and incremental product innovation. } \\
\text { Radical product innovation and incremental product } \\
\text { innovation have a positive impact on marketing } \\
\text { performance. }\end{array}$ & $\begin{array}{l}\text { The company's ability to } \\
\text { develop product } \\
\text { innovation, both radical } \\
\text { product innovation and } \\
\text { incremental product } \\
\text { innovation have a } \\
\text { positive impact on } \\
\text { marketing performance. }\end{array}$ \\
\hline $\begin{array}{l}\text { Li and } \\
\text { Huang } \\
(2012)\end{array}$ & $\begin{array}{l}\mathrm{Li} \text { and Huang (2012) describe the model in his research } \\
\text { that is the marketing skills are positively related to high } \\
\text { skills. Technical skills are positively associated with } \\
\text { high skills. Marketing skills are positively related to } \\
\text { performance. Technical ability is positively related to } \\
\text { performance. High skills are positively related to the } \\
\text { performance of new products. High skills mediate the } \\
\text { relationship between marketing skills and performance. } \\
\text { High skills mediate the relationship between technical } \\
\text { proficiency and performance. }\end{array}$ & $\begin{array}{l}\text { The hand skills that } \\
\text { reflect the interaction } \\
\text { between exploitation and } \\
\text { exploration play a role as } \\
\text { mediating a positive } \\
\text { relationship between } \\
\text { product development } \\
\text { capability and marketing } \\
\text { performance. }\end{array}$ \\
\hline
\end{tabular}




\begin{tabular}{|c|c|c|}
\hline $\begin{array}{l}\text { Tooksoon } \\
\text { and } \\
\text { Mohamad } \\
(2010)\end{array}$ & $\begin{array}{l}\text { Tooksoon and Mohamad (2010) describe the model in } \\
\text { their research that is marketing ability consisting of } \\
\text { product development capability and price capability have } \\
\text { an effect on export performance, and export dependency } \\
\text { mediate the influence of marketing ability consisting of } \\
\text { product development capability and price capability to } \\
\text { marketing performance. }\end{array}$ & $\begin{array}{l}\text { Pricing capabilities and } \\
\text { promotional capabilities } \\
\text { are significant and } \\
\text { positively related to } \\
\text { marketing performance, } \\
\text { while product } \\
\text { development capabilities } \\
\text { and distribution } \\
\text { capabilities are not } \\
\text { positively related to } \\
\text { marketing performance. }\end{array}$ \\
\hline $\begin{array}{l}\text { Ramaswami } \\
\text { et al., } \\
(2009)\end{array}$ & $\begin{array}{l}\text { Ramaswami (2009) describes the model in his research } \\
\text { that is the intensity of research and development affect } \\
\text { the company's financial performance through the } \\
\text { performance of new product development, the } \\
\text { development of customer control affects the financial } \\
\text { performance of the company through the performance of } \\
\text { new product development, integration cross-division } \\
\text { affect the financial performance of the company through } \\
\text { development performance new product. Customer asset } \\
\text { orientation affects the company's financial performance } \\
\text { through the performance of customer management, } \\
\text { focusing on high value of the customer influence to } \\
\text { company's financial performance through the } \\
\text { performance of customer management, response to } \\
\text { customer influence to company's financial performance } \\
\text { through customer management performance. Sharing } \\
\text { info and decisions affect the company's financial } \\
\text { performance through the performance of supply chain } \\
\text { management, supply chain leadership affects the } \\
\text { company's financial performance through the } \\
\text { performance of supply chain management. }\end{array}$ & $\begin{array}{l}\text { New } r \text { product } \\
\text { development capability } \\
\text { is not significant to } \\
\text { marketing performance. }\end{array}$ \\
\hline $\begin{array}{l}\text { Liu et al., } \\
\text { (2014) }\end{array}$ & $\begin{array}{l}\text { Liu et al., (2014) describes the model in his research that } \\
\text { demographic variables moderate product development } \\
\text { capability on performance. }\end{array}$ & $\begin{array}{lr}\text { Product development } \\
\text { capability with } \\
\text { functional innovation } \\
\text { dimension and marketing } \\
\text { innovation is not } \\
\text { significant to marketing } \\
\text { performance. }\end{array}$ \\
\hline
\end{tabular}

Source: Developed for this study (2018).

The research is also conducted because of the business phenomenon that is the decrease of the number of entrepreneurs and the number of workers in salted egg industry Brebes Regency, Central Java Province, Indonesia. Amrillah (2013) in his research said that the development of the number of salted egg craftsmen and the amount of labor in the salted egg industry in the 1970s until the 2000s fluctuated, as shown in Table 2 below. 
Table 2. Number of Labor of Salted Egg Industry in Brebes Sub-district and Kelurahan Limbangan Wetan Based on Number of Industry 1970s-2000s

\begin{tabular}{|c|c|c|c|}
\hline No. & Year & $\begin{array}{c}\text { Number of Craftsmen (business } \\
\text { unit) }\end{array}$ & Total Labor (person) \\
\hline 1. & $1970 \mathrm{~s}$ & 20 & 60 \\
\hline 2. & $1980 \mathrm{~s}$ & 54 & 260 \\
\hline 3. & $1990 \mathrm{~s}$ & 65 & 178 \\
\hline 4. & $2000 \mathrm{~s}$ & 45 & 260 \\
\hline
\end{tabular}

Source: Amrillah (2013).

Table 2 presents the development of salted egg manufacturers and the number of workers in the salted egg industry in Brebes and Limbangan Wetan urban areas. The total labor force has decreased from 260 in the 1990s to 178 in the 2000s. Likewise, the number of salted egg businessmen decreased during the same period from 65 to 45 entrepreneurs. With this development, as described above, the research question of this study is how to develop a model using product development capability to improve marketing performance.

To improve marketing performance the proposed variable of mediation is the regiocentric product advantage. Regiocentric product advantage is the superiority of the company's products by placing the product in the mind of the region-oriented prospect using the uniqueness of the region, the uniqueness of the product and the irreplaceable product as the regional icon. The benefits of regiocentric products are expected to improve marketing performance.

\section{Literature Review and Hypothesis Development}

\subsection{The Theory of Resource Based View}

The theory of resource based view (RBV) was first introduced by Wernerfelt in 1984. The concept of RBV assumes that the ability of firms to compete is highly dependent on the uniqueness of existing resources within the organization (Wernefelt, 1984). The RBV theory considers that the firm is a collection of resources and assumes that each company has unique resource capabilities and company growth is subject to efficient use of resources and capacity deployment (Wernefelt, 1984). In addition, RBV's theory also sees that the competitiveness of an organization is a function of the uniqueness and value of resources and capabilities possessed by the organization. This theory also assumes that capability is the main source to achieve sustainable competitive advantage. As a concept that has been widely discussed in RBV theory, competitive advantage has been conceptualized 
and embedded in enterprise cost leadership and differentiation in the markets (Bharadwaj et al., 1993).

RBV theory focuses more on the internal side of the company that is about resources owned company. Company capability is an important resource for the company (Grant, 1991). Resources are a major source of competitive advantage and will increase the difficulty of imitating competitors. Proponents of the RBV theory use the company's internal resources, competencies and abilities as important determinants of strategy. This paradigm argues that differences in company performance can be traced back to the heterogeneous assets and capabilities possessed by the company. The RBV theory states that the company's resources and capabilities determine competitive advantage and companies that enjoy superior capabilities compared to their competitors have a significant advantage. Resources are the productive assets owned by the company, while the ability of the company to efficiently exploit resources, to produce products and to develop services is used to achieve its goals (Peteraf, 1993; Russo and Fouts, 1997; Raphael and Schoemaker, 1993). Resources are categorized into real, intangible and human resources. Real resources are capital resources, equipment, factories and others, while the intangible resources are the company's reputation, brand image and the perceived quality of its products. Intellectual capital or human resources are the skills and knowledge of employees, and knowledge-oriented assets (Grant, 1991).

\subsection{The Concept of Orientation of Company Marketing Area}

The concept of a company's marketing region comes from Perlmutter in his book „The Tortuous Evolution of the Multinational Corporation” published in 1969 (Mayrhofer and Brewster, 1996). He proposed three stages of the evolution of marketing orientation of multinational corporations, i.e., ethnocentric orientation (oriented to ethnicity), polycentric orientation (state oriented) and geocentric orientation (global oriented). Perlmutter (1969) approach is based on geocentrism (global mindset) spawned a stream of research that focused on the dimensions of the global cultural environment. Perlmutter's approach is culturally perspective, focusing on aspects of cultural diversity and cultural distances associated with worldwide marketing operations. This underscores the challenge of managing across cultures and national boundaries (Levy et al., 2007).

Ten years later, in 1979, Heenan and Perlmutter (1979) added the fourth area of marketing orientation the regiocentric marketing orientation. The regiocentric marketing orientation is a corporate strategy based on regional considerations, requiring collaboration across national boundaries, but only within a limited geographical sphere. Based on the description, the conceptual approach to the evolution of relevant corporate marketing orientations is used to underlie this research, mainly able to explain the regiocentric marketing orientation which is a corporate strategy based on regional considerations, requiring collaboration across national boundaries, but only within the geographical sphere limited. 


\subsection{The Marketing Mix Concept}

The concept of the marketing mix was first coined by (McCarthy, 1975). Silverman (1995) in his research on the history of the creation of marketing mix concepts that McCarthy was the first to trigger a marketing mix consisting of 4Ps, namely product, place, price and promotion. Products are everything that is offered to the market to get attention, bought, used that satisfy the wants or needs of consumers (Kotler and Armstrong, 2012). Core products create an impact on product success in the markets such as return on investment, employment, market sustainability, product positioning, product pricing and brand equity (Salunke and Srivastava, 2013).

Marketing mix is a set of marketing tools that companies use to continuously achieve their marketing objectives in the target market. Product attributes are part of the marketing mix and define the marketing mix as a set of controllable variables and the level of variables used by firms to influence the target market (Kotler, 2002). The marketing mix has an important role for both the seller and the customer. From the point of view of the seller, this marketing tool serves to apply important values that need to be highlighted in offering products to customers to persuade them to buy the product. From a buyer's point of view this marketing tool is designed to provide benefits for the consumer.

\subsection{The Sustainable Competitive Advantage}

Competitive advantage is the heart of marketing performance to face competition. Competitive advantage is defined as a lucrative strategy of the companies that collaborate to create more effective competitive advantage in their markets. This strategy should be designed to realize continuous competitive advantage so that the company can dominate the market. Competitive advantage basically grows from the values or benefits created by the company for its buyers. Customers generally prefer to buy products that have more value than desired or expected (Porter, 1990).

Competitive advantage is the result of implementing strategies that utilize various resources owned by the company. Unique expertise and assets are seen as the source of competitive advantage. This unique skill is the company's ability to make its employees an important part of achieving competitive advantage. The company's ability to develop the skills of its employees well will make the company superior and the implementation of human resource-based strategies will be difficult to imitate by its competitors. Moderate assets or unique resources are the real resources the company needs to run its competitive strategy. Both of these resources should be directed to support the creation of low cost enterprise performance and differentiation with other companies (Bharadwaj and Fahy, 1993). In addition, companies can enjoy competitive advantage through the company's superior knowledge, competence or ability to conduct and manage business processes, produce lower-cost product quality and deliver the right products and / or services to 
customers at the right place at the price and time through the right channel (Ma, 2004).

\subsection{Marketing Performance}

Organizational performance can be seen from the marketing performance, financial performance and human resource performance. The company's strategy is always directed to generate marketing performance (sales volume), market share and sales growth and financial performance (Ferdinand, 2000). Marketing performance is defined as measuring business performance levels including sales turnover, number of buyers, profits and sales growth (Voss and Voss, 2000). Gama (2011) in his research adds five dimensions of new marketing performance: marketing culture, marketing ability, marketing process, market performance and financial performance. While an important element in the measurement of marketing performance refers to the tools used in the process of marketing performance. The most popular tools are as follows: marketing performance indicators, marketing dashboard and marketing performance management system (Mone et al., 2013).

\section{Mapping State of the Art Concept of Regiocentric Product Advantage}

Based on the approach of RBV theory, the concept of marketing mix and the concept of orientation of company marketing area can be arranged as the basic theory in this research as shown in Figure 1.

\subsection{Regiocentric Product Advantage}

The competitive advantage of the product is superiority and / or higher distinction compared to competitors' offer (Henard and Szymanski, 2001). The elements of product advantage, such as the uniqueness, value and benefits the company offers must be viewed from a customer perspective, based on the understanding of the needs and desires of customers, as well as from their subjective factors (likes and dislikes). Product advantages may be positively associated with product market performance, which refers to competitive and financial outcomes in the market, as indicated in profit, return on investment and market share. The buyer usually forms a pleasant perception of a product with superior features (Carpenter and Nakamoto, 1989) and they choose the product in terms of purchase preferences and actual behavior when the benefits of this product go beyond price (Alpert and Kamins, 1995).

Product attributes such as product quality, reliability, novelty and uniqueness can provide a more tangible picture of a company's ability to meet customer needs and and alternatives and direct evidence of its superiority. Song and Parry (1997) comparing new product development projects reported that a project would be more 
Figure 1. Mapping State of The Art Concept of Regiocentric Product Advantage

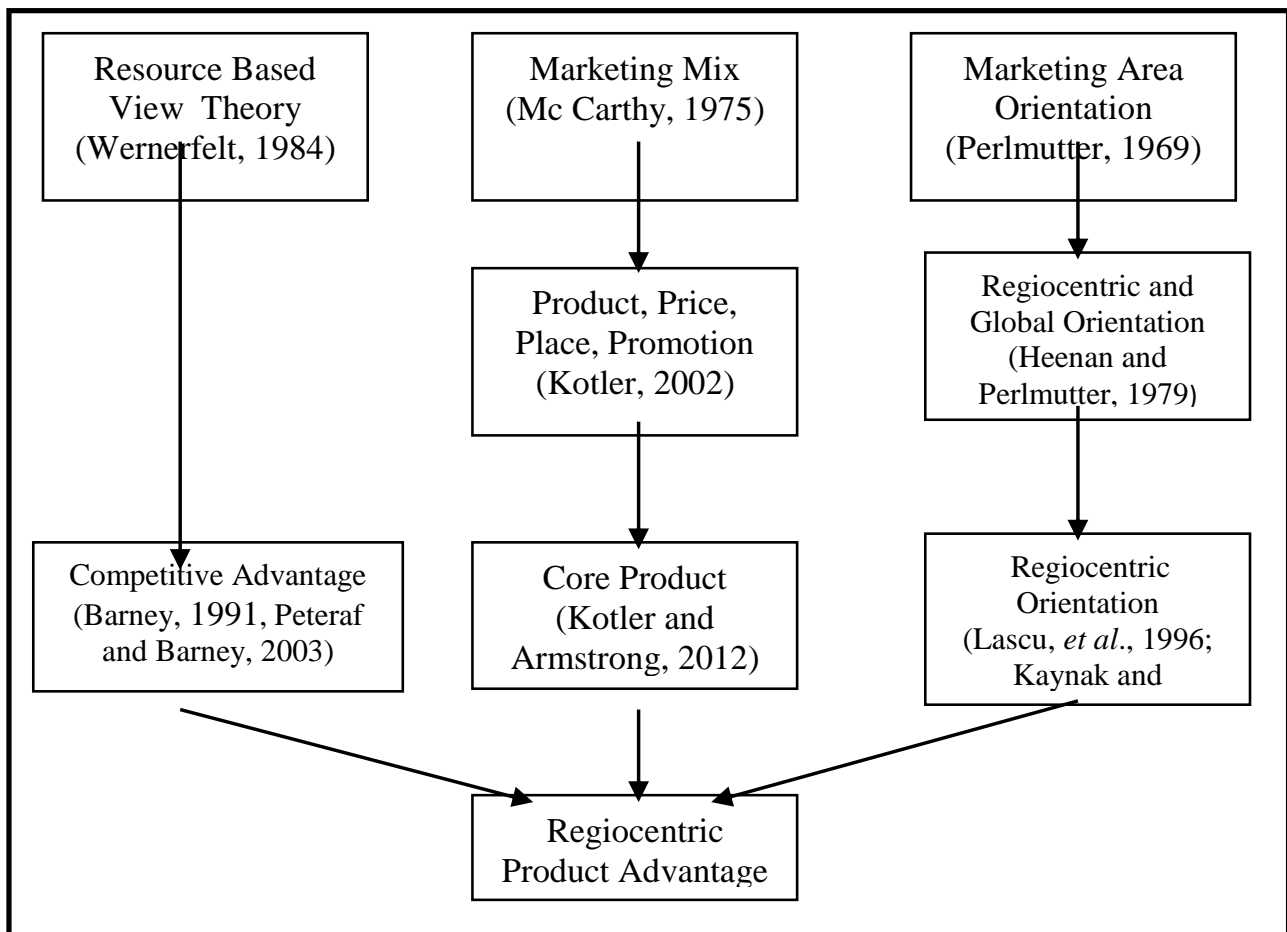

Source: Developed for this study (2018).

likely to succeed if the product had a strong competitive advantage. Products that have a high competitive advantage will have higher success rates, gain greater market share, have higher profits and achievable sales and profit achievement targets (Cooper 1994). The most important factor that leads to a successful product is the superiority of the product. Superior products will determine the win or defeat of products that fight in the market (Cooper, 1994).

Regiocentric product advantage is a series of great value proposals from the company to the mind of the region-oriented prospect by using the uniqueness of the region, the uniqueness of the product and the irreplaceable product as a regional icon. Regiocentric product advantage are expected to improve marketing performance. Based on the study of theory and the results of this research, this proposition is based on RBV theory which focuses more on the internal side of the company that is about internal resources owned by the company. In order to have sustainable competitive advantage, resources must meet the four requirements that must be valuable, unique and rarely owned by either current or potential competitors, can not be imitated perfectly and are strategically irreplaceable. To gain competitive advantage, companies must focus on internal resource use, competency and capability. Unique capabilities and assets are seen as the source of competitive 
advantage (Barney, 1991). This is a major source of competitive advantage and will increase the difficulty of imitating competitors.

Based on the description, the conceptual approach to the evolution of relevant corporate marketing orientations is used to underlie this research, mainly able to explain the regiocentric marketing orientation which is a corporate strategy based on regional considerations, does not require collaboration across national boundaries, but only within the geographical / limited places. It can be formulated that regiocentric product advantage is the superiority of the company's products in placing the product to the mind of the region-oriented prospect by using the uniqueness of the region, the uniqueness of the product and the irreplaceable product as the regional icon. Regiocentric product advantage are expected to increase marketing performance as stated before.

\section{Hypothesis Development and Empirical Research Model}

To detail the proposition which has been proposed above, further study is conducted to formulate some hypothesis as follows:

\subsection{The Relationship of Regiocentric Product Image Capability to Product Regiocentric Avantage}

Kotler (2002) defines the image as a set of beliefs, ideas and impressions a person has on an object where the attitude and object of a person's actions against an object is conditioned by the image of the object. Image is one way to distinguish a product from other products. Imaging is an attempt to build a public impression (image) of yourself or your company in accordance with the general expectations. The image is obtained through a good understanding of the public against the object being imaged. Imaging is done by building a good understanding of the public through the provision of complete information about the object being imaged. The value or usefulness of the imagery can be subjective or objective depending on the philosophical point of view. Imagery can be negative if it is only carried out by the principle of a spin doctor or machiavellis, that is to twist information only so that the imaging object "looks" good.

One of the factors influencing competitive advantage is corporate image (Smith and Barclay, 1999). The packaging design that is a product image is also an important factor contributing to the differentiation of competitors and potentially leading to competitive advantage (Rundh, 2009). Product packaging is considered an essential component of modern lifestyles and through the company's business packaging can be regulated. There are four dimensions of packaging consisting of product and consumer protection; promotion of products, storage facilities, use, and convenience of products. Facilitation of recycling and reduction of environmental degradation affect the perception of consumer product quality on purchasing (Abdalkrim and AL-Hrezat, 2013). Packaging is a tool to compete. There are several important 
factors of packaging that affect the competitive advantage, namely packaging durability, ease of distribution, customer promotion through packaging structures, packaging for silent advertising, packaging diversity, healthy and clean packaging and packaged innovation (Chaudhary, 2014). Therefore, the proposed hypothesis is as follows :

H1: The higher regiocentric product image capability, the higher regiocentric product advantage.

\subsection{Relationship of Product Development Capability to Regiocentric Product Advantage}

Kotler and Armstrong (2012) define product development as an original product development for companies and markets, product improvement / refining of old products, product modifications and new brands through enterprise-owned product development companies. Five dimensions of product development capabilities according to Ulrich and Eppinger (2004) is the ability to improve product quality, product cost efficiency capability, product development time efficiency and product development capability. While the definition of product development capability is the company's ability to perform a series of activities starting from the perception of market opportunities and ending with production, sales and delivery of products.

The company's ability to develop and launch successful products in the Nigerian consumer market requires that potential producers to conduct competitive intelligence research in detail about the company's operating environment. It equally requires manufacturers to continuously monitor and analyze the external influences that affect choice, consumer needs and consumer expectations and also acquire and analyze relevant data on competitors' strategies, strengths and weaknesses. This will help product development based on the reality of time, thus promoting sustainable competitive advantage (Agboh, 2014). Each company has a unique set of sources and capabilities, and some types of capabilities will be closer to performance with superior competitor (Yu et al., 2014). Product development (both gradual product development and integral product development) has a significant effect on the company's competitive advantage (Soltani et al., 2014). The proposed hypothesis is as follows :

H2: The higher product development capability, the higher the regiocentric product advantage.

\subsection{Relationship Customer Sensing Quality to Regiocentric Product Advantage}

The ability to sense the market provides new insight into the company's products and services offered, and great value to customers and their distribution channels (Slatter and Narver, 2000). One of the variables of market knowledge competence is customer knowledge management. Customer knowledge management consists of 
three dimensions: gaining knowledge of customers, translating customer knowledge and incorporating customer knowledge ( $\mathrm{Li}$ and Calantone, 1998). Tregear et al., (1998) study states that companies should be able to communicate with markets and ensure that the distinctive attributes of a company's products must be recognized by consumers. The ability of market sensing as one way to facilitate understanding of the creation of market orientation (Foley and Fahy, 2004). Firms with marketsensing capabilities will be able to accurately predict the value of different resources, allowing them to avoid paying more than the required resources (Makadok, 2001).

Sensing is a set of organizational mechanisms to continually acquire, communicate and act on trends and events in the corporate environment (Weick et al., 2005). When companies are equipped with market sensing capabilities, they typically involve competencies of strategic information exchange, strategic complexity and some perspective considerations (Neill et al., 2007). As for members of the new product development team, they can efficiently integrate multiple perspectives on market information that can lead them to be more effective at configuring and deploying resources, thereby gaining the influence of resources to serve superior customer value.

The ability of the company's sensing is an important capability that is essential to changing the potential benefits (access to information and safe environments) and realizing the results of new product development (Zhang and $\mathrm{Wu}$, 2013). Sensing ability is related to achieving competitive advantage by being mediated by environmental marketing strategies. The environmental marketing strategy comprises policies, practices and procedures in a marketing context that incorporate an environmentally-focused strategy, with the goal of creating revenue and profits to achieve organizational and individual objectives (Leonidou et al., 2013). The proposed hypothesis is as follows :

H3: The higher the customer sensing quality, the higher the regiocentric product advantage.

\subsection{Relationship of Regiocentric Product Advantage to Marketing Performance}

There are three strategies that can be implemented by companies to gain competitive advantage, namely cost-benefit strategy, differentiation strategy and focus strategy. Competitive advantage is the core of enterprise performance in the competitive market. Competitive advantage basically grows from the value or benefits the company, can create for its buyers greater than the cost that companies must incur to create it. There are 5 dimensions of competitive advantage that is product specificity, competitive price, rarely found, difficult to imitate and difficult to replace (Bharadwaj et al., 1993). 
Competitive advantage positively affects marketing performance as measured by sales volume, profit rate, market share and return on investment (Li, 2000). Unique advantages have a reasonable influence on the relationship between linkage ambiguity and organizational performance (King et al., 2001). Langerak et al. (2004) states that product excellence and proficiency in launch tactics are positively related to new product performance, and it is positively related to organizational performance. Likewise, Newbert (2008) found that competitive advantage was positively related to performance while (Kamboj et al., 2015) found that competitive advantage completely mediates marketing ability to financial performance.

Bryla (2015) states that the authenticity felt from food products is closely related to its origin, expressed by time (history), place (localization), socialization (local people) and rawness of raw materials. Scale to measure the authenticity of food products includes the following dimensions: origin, naturalness, identity (relation to personality and consumer style) and uniqueness. On the demand side, growing consumer preferences are more attracted to regional food products with high quality and health attributes as well as their interest in food products that relate to a particular geographic region or come from a particular region. Therefore the proposed hypothesis is as follows :

H4: The higher the regiocentric product advantage the higher the marketing performance.

Based on the developed hypothesis and literature review the empirical research model is presented as shown in Figure 2.

Figure 2. Empirical Research Model

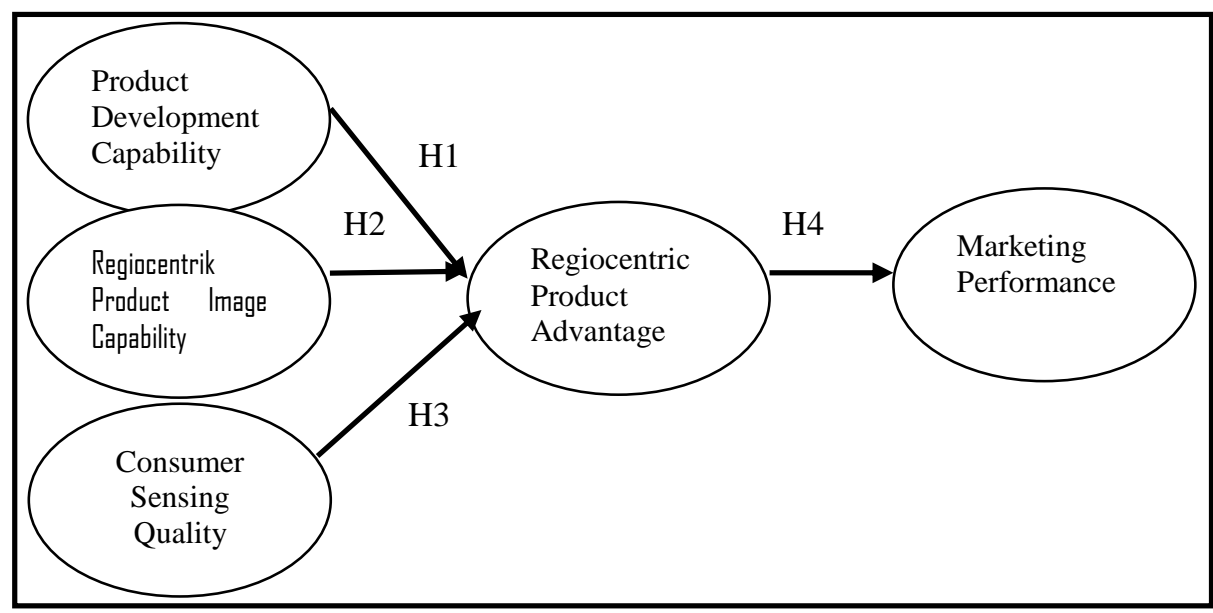

Source: Developed for this study (2018). 


\section{Research Methodology}

The study used primary data obtained by interview based on questionnaires to a number of selected respondents. The research design used in is of descriptive type. Data collection was done by a survey method through a structured questionnaire with ten points scoring scale. Questionnaires were processed and analyzed by Structural Equation Modeling using AMOS 22.

The research was conducted using the population of salted egg business entrepreneurs, 404 salted egg entrepreneurs in Brebes, Central Java Province, Indonesia (Hanfan, 2016). The number of samples used is 118 respondents, this number meets the minimum sample criteria recommended by Hair et al. (2010) stating that the sample size must be 5 times the number of indicators. This study the number of indicators is 15 , then the number of samples used in this study is $5 \times 15=$ 75 samples. By using a sample of 118 respondents, the requirement of the sample size has been fulfilled.

The sampling technique is based on random sampling because sampling is performed on random members of the population regardless of the strata in the population. This is done because members of the population are considered homogeneous. The random sampling was obtained by drawing, using random numbers. Sampling is done in such a way that it will ensure that the selection of elements to be researched is based on objectivity, not subjectivity.

The study used primary data obtained from questionnaires distributed directly to salted egg entrpreneurs in Brebes District, Central Java Province, Indonesia. Data collection is done through survey, which is done by asking the respondent. The survey method in this study was conducted using research instruments such as questionnaires with open questions consisting of items representing independent variables and dependent variables. The questionnaires were distributed to the respondents directly, so the respondent could provide the value and the short answer of the available open questions. The questionnaire was made by giving the answer value (1) strongly disagree to (10) strongly agree.

\subsection{Operational Measurements and Indicators}

The definition of each variable needs to be explained in a more operational size. Each variable has a very relevant meaning to the context of the variable in the research model. Explanations from various experts on meaning, antecedents and variable consequences are transfused in the core definition to sharpen the explanation of variables. A variable has been described in general about what to be studied but the measurement of these variables need to be concretized through operational measurement which then becomes a reflective indicator of the variables (Table 3). 
Table 3. Operational Definition and Indicator

\begin{tabular}{|c|c|c|}
\hline Variables & Operational definition & Indicator \\
\hline $\begin{array}{l}\text { Product } \\
\text { Development } \\
\text { Capability }\end{array}$ & $\begin{array}{l}\text { The company's ability to } \\
\text { develop original products for } \\
\text { companies and markets, old } \\
\text { product improvements, new } \\
\text { product and brand } \\
\text { modifications through } \\
\text { company-owned product } \\
\text { development efforts. }\end{array}$ & $\begin{array}{l}\text { X1: Capability to make various flavors of salted } \\
\text { egg. } \\
\text { X2: Capability to modify the type of salted egg. } \\
\text { X3: Capability to create an unsmiling odor on } \\
\text { salted eggs. }\end{array}$ \\
\hline $\begin{array}{l}\text { Regiosentric } \\
\text { Product Image } \\
\text { Capability }\end{array}$ & $\begin{array}{l}\text { Cpaability of companies to } \\
\text { build public impression of } \\
\text { regiocentric products in } \\
\text { accordance with company } \\
\text { expectations. }\end{array}$ & $\begin{array}{l}\text { X4: Capability to guarantee the quality of salted } \\
\text { eggs. } \\
\text { X5: Capability to maintain good reputation / } \\
\text { prestige of salted eggs. } \\
\text { X6: Capability to promote salted eggs. }\end{array}$ \\
\hline $\begin{array}{l}\text { Customer } \\
\text { Sensing } \\
\text { Quality }\end{array}$ & $\begin{array}{l}\text { The degree of conformity of } \\
\text { the company in reciprocal } \\
\text { interaction with information } \\
\text { seeking, customer } \\
\text { assumptions and actions. }\end{array}$ & $\begin{array}{l}\text { X7: Monitoring the ups and downs of market } \\
\text { demand. } \\
\text { X8: Ability to adapt to changing market tastes. } \\
\text { X9: Utilization of information from customers. }\end{array}$ \\
\hline $\begin{array}{l}\text { Regiocentric } \\
\text { Product } \\
\text { Advantage }\end{array}$ & $\begin{array}{l}\text { Regiocentric product } \\
\text { advantage is the superiority } \\
\text { of the company's products in } \\
\text { placing the product to the } \\
\text { mind of the region-oriented } \\
\text { prospect by using the } \\
\text { uniqueness of the region, the } \\
\text { uniqueness of the product and } \\
\text { the irreplaceable product as } \\
\text { the regional icon. }\end{array}$ & $\begin{array}{l}\text { X10: Superiority of salted eggs as regional icons. } \\
\text { X11: A variety of unique salty egg taste. } \\
\text { X12: The type of salted egg that is difficult to } \\
\text { imitate. }\end{array}$ \\
\hline $\begin{array}{l}\text { Marketing } \\
\text { Performance }\end{array}$ & $\begin{array}{l}\text { The concept of measuring the } \\
\text { impact of a company's } \\
\text { strategy as a reflection of } \\
\text { existing market activity } \\
\text { includes increased sales } \\
\text { volume, market share and } \\
\text { profits. }\end{array}$ & $\begin{array}{l}\text { X13: Sales growth. } \\
\text { X14: Sales volume. } \\
\text { X15: Sales profit. }\end{array}$ \\
\hline
\end{tabular}

Source: Developed for this study (2018).

\subsection{Variable Measurement}

Each variable is explained by some of the indicators that form the questionnaire. Each indicator is derived from theoretical explanations and empirical studies of previous research. With SPSS 16.0 and AMOS 22.0 software each indicator is also tested to the extent that its ability to explain the variables is a construct measurement consisting of the Cronbach $\alpha$ parameter test and the measurement model test seen 
from the loading value of each construct factor with confirmatory factor analysis (CFA). The results of the overall construction test can be seen in Table 4.

Table 4. Construct Validity

\begin{tabular}{|l|c|}
\hline \multicolumn{1}{|c|}{ Variable } & Loading Faktor \\
\hline Product Development Capability & $\mathrm{X} 1=0.803$ \\
& $\mathrm{X} 2=0.821$ \\
& $\mathrm{X} 3=0.760$ \\
\hline Regiosentric Product Image Capability & $\mathrm{X} 4=0.871$ \\
& $\mathrm{X} 5=0.853$ \\
& $\mathrm{X} 6=0.839$ \\
\hline Customer Sensing Quality & $\mathrm{X} 7=0.871$ \\
& $\mathrm{X} 8=0.835$ \\
\hline Regiocentric Product Advantage & $\mathrm{X} 9=0.843$ \\
& $\mathrm{X} 10=0.903$ \\
& $\mathrm{X} 11=0.902$ \\
\hline Marketing Performance & $\mathrm{X} 12=0.826$ \\
\hline & $\mathrm{X} 13=0.866$ \\
& $\mathrm{X} 14=0.821$ \\
\hline
\end{tabular}

Source: Developed for this study (2018).

Variable product development capability is measured by the indicator of ability to make various tastes of salted egg, ability to modify salted egg type, ability to create odor that is not fishy on salted egg with value factor of each factor equal to 0803 , 0.821 and 0.760 respectively. The regiocentric product imaging capability variable is measured by indicators of the ability to ensure the quality of salted eggs, the ability to maintain good reputation / salted egg prestige, the ability to promote salted eggs with loading factor values of $0.871,0.853$ and 0.839 . Customer quality sensing variable is measured by monitoring indicators of the ups and downs of market demand, the ability to adapt to changing market tastes, utilization of information from customers with a value of loading factor of $0.871,0.835$ and 0.843 . The variable of regiocentric product advantage is measured by the indicator of the superiority of salted eggs as regional icons, the unique taste of salted eggs, the hardy salted eggs with the loading factor values of $0.903,0.902$ and 0.826 .

Marketing performance variable is measured by sales growth indicator variables, sales volume, sales profit with loading factor value of each $0.866,0.821$ and 0.763 . Each indicator has the power of explaining the variable / construct ideally because the loading factor is above 0.7 (Ghozali, 2011). Customer quality sensing variables are measured by monitoring indicators of the ups and downs of market demand, the ability to adapt to changing market tastes, utilization of information from customers with a value of loading factor of $0.871,0.835$ and 0.843 . The variables of excellence of the regiocentric product were measured by the indicator of the superiority of salted eggs as regional icons, the unique taste of salted eggs, the hardy salted eggs with the loading factor values of $0.903,0.902$ and 0.826 . Marketing performance variables are measured by sales growth indicator variables, sales volume and sales 
profit with each loading factor value of $0.866,0.821$ and 0.763 . Each indicator has the power of explaining the variable ideally because the loading factor is above 0.7 (Ghozali, 2011).

\subsection{Full Model Test}

Here is a picture of the full test model in this study (Figure 3):

Figure 3. Full Model Test

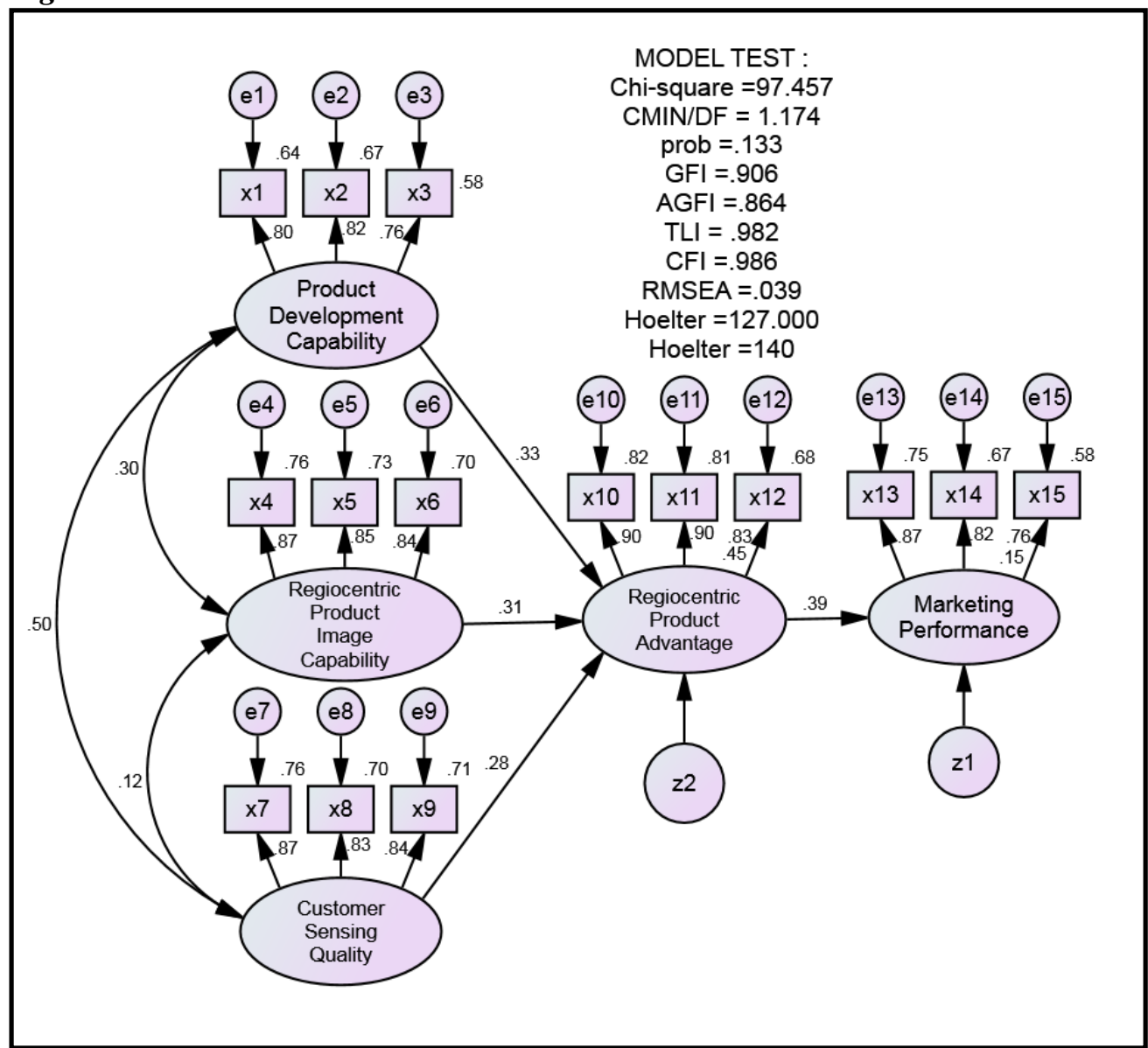

Source: Primary data processed (2018).

Table 5. Goodness of Fit Full Model

\begin{tabular}{|l|l|l|l|}
\hline Goodness of Fit Index & Cut-Off Value & Analysis Result & $\begin{array}{l}\text { Model } \\
\text { Evalution }\end{array}$ \\
\hline Chi-Square & Diharapkan kecil & 97.457 & Good \\
CMIN/DF & $\leq 2.00$ & 1.174 & Good \\
Probability & $\geq 0.05$ & 0.133 & Good \\
RMSEA & $\leq 0.08$ & 0.039 & Good \\
GFI & $\geq 0.90$ & 0.906 & Good \\
\hline
\end{tabular}




\begin{tabular}{|l|l|l|l|}
\hline AGFI & $\geq 0.90$ & 0.864 & Marginal \\
TLI & $\geq 0.95$ & 0.982 & Good \\
CFI & $\geq 0.95$ & 0.986 & Good \\
Hoelter's 0,05 & $\leq 127$ & 118 & Good \\
Hoelter's 0,01 & $\leq 140$ & 118 & Good \\
\hline
\end{tabular}

Source: Primary data processed (2018).

The results of processing the full model test using AMOS 22.0 analysis tool obtained goodness of fit results as follows, namely the value of Chi-Square $=97.457$; CMIN / $\mathrm{DF}=1.174 ;$ probability $=0.133 ; \mathrm{RMSEA}=0.039 ; \mathrm{GFI}=0.906 ; \mathrm{AGFI}=0.864 ;$ TLI $=0.982 ; \mathrm{CFI}=0.986$. Further statistics of the last goodness of fit is critical $\mathrm{N}$ developed by (Hoelter, 1983). The critical $\mathrm{N}$ analysis is intended to estimate the size of the sample size sufficient to produce a good fitted model. The model is said to be able to produce a goodness of fit if it has a sample below of the Hoelter value tested both with a probability of 0.05 and 0.01 . Here are the results of $\mathrm{N}$ Hoelter's critical analysis 0.05 and Hoelter's 0.01 , Hoelter's $0.05=127$; Hoelter's $0.01=140$ which all meet the fit criteria because the number of samples is below Hoelter's value as recommended (Ferdinand, 2014). Therefore, the results of the Table above show that the conformity test of this model produces a good level of acceptance.

\section{Testing Hypothesis and Conclusion}

The hypothesis proposed, tested using the AMOS 22.0 analysis tool is as follows :

Table 6. Full Model Test Results

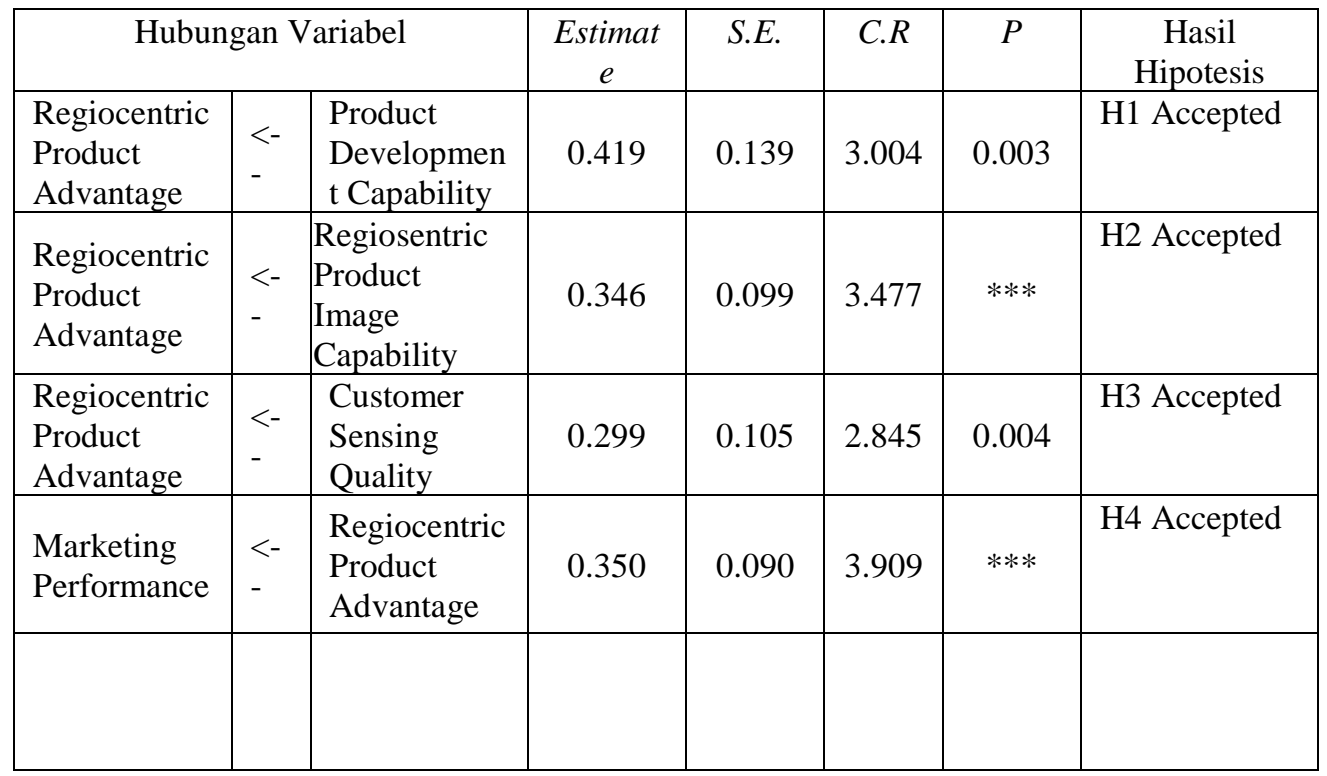

Source: Primary data processed (2018). 
Testing the hypothesis as listed in Table 6 , it can be concluded that hypothesis 1 shows significant results with the value of $\mathrm{CR}=3.004>1.96$ with probability $=$ 0.003 , the probability of testing is eligible under 0.05 . Thus H1 in this study is accepted. Testing hypothesis 2 showed significant result with value of $\mathrm{CR}=3.477$ > 1.96 with probability $=0.000$; the probability of testing qualifies value below 0.05 . Therefore $\mathrm{H} 2$ is also accepted in this study. Testing hypothesis 3 shows significant results with $\mathrm{CR}=2.845>1.96$ with probability $=0.004$, the probability of testing is eligible under 0.05 . H3 in this study is accepted. Testing hypothesis 4 shows significant results with value $\mathrm{CR}=3.909>1.96$ with probability $=0,000$ the probability of testing is eligible under 0.05 so $\mathrm{H} 4$ is also accepted.

\section{Managerial and Theoretical Implication, Limitation and Future Research}

The managerial implications generated in this study are the following: the ability of salted egg companies to make the taste of products less salty should be maintained as it is the first step towards healthy food; developing salty egg products that taste less salty, Brebes salted eggs can be healthier food. The company's ability to create low moisture content in its products is maintained so that the product can last much longer and in creating a stinky odor on its products should still be improved, in order for consumers to continue to like the product. The company must also be able to develop a variety of flavors of its products, so that consumers have a great selection of flavors to the company's products. The company's ability to modify its product type should also be improved, so that consumers have many choices for the company's product range.

The ability of the company to ensure product quality, improve the image / impression of the taste of the product, introduce the product, maintain the good name / product prestige, add product attractiveness and adjust the customer's taste change should be increased. So that consumers always believe, feel, have the desire to buy, feel proud to buy and consumers are more interesting in company's products. The company's ability to utilize information to find out customer wishes, accommodate customer complaints, observe product prices and monitor product demand should be increased so as to know the tastes desired by customers, identify customer complaints, improve product quality, know the price of products from competitors and companies can meet market demand. The salted egg company must survive in making its distinctive products of color, texture and smell, create products with different flavors, create products with unique tastes, create products that are hard to imitate, to keep consumers happy and loyal to the company's products. Companies should also be more vigorous to develop superior products as regional icons, so that the product will be sought and purchased by consumers because of its product superiority as a regional icon. Thus Brebes salted eggs become top of mind, embedded more deeply in the minds of consumers to become a generic brand of salted egg products. 
The company must maintain the value of product sales, in order to keep the company's marketing performance up. The company must also maintain sales growth, in order to keep the company's marketing performance up. Then the company must increase its sales profits, so that its marketing performance is still increasing. The company must also increase its sales volume, in order to improve its marketing performance. Then the company should use other strategies as an effort to improve marketing performance, for example through means of promotion through social media such as facebook, twitter, WhatsApp, instagram and through sales on line. Although the findings of this study indicate that marketing performance has increased, it is important for related institutions such as the Industry and Trade Office of Brebes, Cooperatives and SMEs of Brebes District, Brebes District Health Office and Integrated Licensing Service Office of Brebes Regency to encourage the salted egg industry through mapping activities industrial growth, socialization of regulations related to SMEs and encourage the establishment of more industrial clusters. The findings of this study also recommend the related institutions for the facilitation of salted egg companies in increasing the sales of their products, for example by meperbanyak exhibition of excellent products exhibition on the regional scope and exhibition on the national scope.

Theoretical implications provide an overview of the references used in this study, whether they will be the reference to problems, modeling, results and prior research agenda. Theoretical implications are a reflection of every study. From the analysis of the full model the theoretical implication received is that when a company has an aim to improve marketing performance the company needs to consider how to improve the superiority of the regiocentric product. The superiority of regiocentric products is supported by product development capability, regiocentric product imaging capability and customer sensing quality.

The findings of this study have limitations related to results and processes in conducting research in the full model test. There is a criterion whose value is still marginal i.e., AGFI value of 0.864 , because it is required to be less than or equal to 0.90 . The number of samples in this study used 118 respondents. Although the number of samples has been deemed to qualify the minimum sample size in the SEM test, in future studies the number of samples should be coupled with the aim of improving the generalization of the results. The place of this research is conducted only in one regiocentric product producing region that is in Brebes Regency, Central Java Province as producer of salted egg. In a future research can add another regiocentric product producing region, for example Semarang City as a regiosentric product of milkfish presto, lumpia or wingko tripe. Thus, can improve the generalization of research results.

Based on the limitations of this research, there are several future research topics that can be considered by introducing variables that consider innovation of environmentally friendly products such as corporate branding variables. 


\section{References :}

Abdalkrim, G.M. and AL-Hrezat, R.I.S. 2013. The Role of Packaging in Consumer's Perception of Product Quality at the Point of Purchase. European Journal of Business and Management, 5(4), 69-82.

Agboh, I.C. 2014. Competitive Intelligence Framework for Product Development: An Antidote to Manufacturers Penetration of Nigerian Consumer Market. Global Conference on Business and Finance Proceedings, 9(2), 28-36.

Alpert, F.H. and Kamins, M.A. 1995. An empirical investigation of consumer memory, attitude and perceptions toward pioneer and follower brands. Journal of Marketing, 59(4), 34-45.

Amit, R. and Schoemaker, P.J.H. 1993. Strategic Assets and Organizational Rent. Strategic Management Journal, 14, 33-46.

Amrillah, D.H. 2013. Development of Salted Egg Industry in Limbangan Wetan Village, Brebes Subdistrict and its Impact on Community Socioeconomics 1980 - 2005. Thesis, Department of History, Faculty of Social Sciences, Semarang State University.

Azizi, S., Movahed, S.A. and Khah, M.H. 2009. The effect of marketing strategy and marketing capability on business performance. Case study: Iran's medical equipment sector. Journal of Medical Marketing, 9, 309-317.

Baker, W.E., Sinkula, J.M. 2005. Environmental Marketing Strategy and Firm Performance: Effects on New Product Performance and Market Share. Academy of Marketing Science, 33(4), 461-475.

Barney, J. 1991. Firm Resources and Sustained Competitive Advantage. Journal of Management, 17(1), 99-120.

Barney, J.B. 1996. Organizational Culture: Can It Be a Source of Sustained Competitive Advantage? Academy of Management Review, 11, 656-665.

Bharadwaj, S.G., Varadarajan, P.R. and Fahy, J. 1993. Sustainable Competitive Advantage in Service Industries: A Conceptual Model and Research Propositions. Journal of Marketing, 57(4), 83-99.

Bryla, P. 2015. The role of appeals to tradition in origin food marketing. A survey among Polish consumers. Appetite, 91, 302-310.

Carpenter, G.S. and Nakamoto, K. 1989. Consumer Preference Formation and Pioneering Advantage. Journal of Marketing Research, 26(3), 285-298.

Chaudhary, S. 2014. Packaging as a Competition Tool. International Journal in IT and Engineering, 02(02), 1-7.

Cooper, R.G. 1994. New products: The factors that drive success. International Marketing Review, 11(1), 60-76.

Dosi, G., Teece, D.J. 1998. Organizational Competencies and the Boundaries of the Firm. Markets and organization, 281-301.

Dutta, S., Narasimhan, O., Rajiv, S. 1999. Success in high-technology markets: Is marketing capability critical? Marketing Science, 18(4), 547-568.

Ferdinand, A. 2014. Structural Equation Modeling: In Management Research. edited by E. 5. BP Undip, Semarang.

Ferdinand, A.T. and Lumban Batu, Kardison. 2013. MaIsCap-Marketing Architectural Isolating Capability as Antecedents for Success of New Produst Development, Journal of Economics, Business, and Accountancy Ventura, 16(3), 487-502.

Ferdinand, A.T. 2000. Marketing Management: A Strategic Approach. Research Paper Series 01 (Mark / 01), 1-55. 
Ferdinand, A.T. 2003. Sustainable Competitive Advantage: A Conceptual Exploration Model, edited by S.P.M.N.M. Reseach Paper Series. Fakultas Ekonomi Universitas Diponegoro, Semarang.

Foley, A. and J. Fahy. 2004. Towards a further understanding of the development of market orientation in the firm: a conceptual framework based on the market-sensing capability. Journal of Strategic Marketing, I(2), 219-230.

Foss, N.J. 1999. Networks, capabilities and competitive advantage. Scandinavian Journal of Management, 15, 1-15.

Gama, A.P.D. 2011. An expanded model of marketing performance. Marketing Intelligence \& Planning, 29(7), 643-661.

Ghozali, I. 2011. Structural Equation Model: Concepts and Applications with the AMOS Program 19.0 edited by IV. Semarang: Diponegoro University Economics S3 Program.

Grant, R. 1991. The Resourced - Based Theory of Competitive Advantage: Implications for Strategy Formulation. California Management Review, 33, 114-135.

Hair, J.F., Black, W.C., Babin, B.J. and Anderson, R.E. 2010. Multivariate Data Analysis, edited by P.P. Hall.

Heenan, D.A., Perlmutter, H.V. 1979. Multinational Organization Development. The International Executive, 21(2), 21.

Hanfan, A. 2016. Building the Excellence of Regiosentric Products to Improve Marketing Performance, Doctoral Program in Economics of Diponegoro University Semarang, Indonesia.

Henard, D.H. and Szymanski, D.M. 2001. Why some new products are more successful than others. Journal of Marketing Research, 38(3), 362-375.

Hoelter, J.W. 1983. The analysis of covariance structures: Goodness-of-fit indices. Sociological Methods and Research, 11, 325-344.

Hoonsopon, D., Ruenrom, G. 2012. The Impact of Organizational Capabilities on the Development of Radical and Incremental Product Innovation and Product Innovation Performance. Journal of Managerial Issues, XXIV(3), 250-276.

Kamboj, S., Goyal, P. and Rahman, Z. 2015. A resource-based view on marketing capability, operations capability and financial performance: An empirical examination of mediating role. Procedia - Social and Behavioral Sciences, 189, 406-415.

Kaynak, E., Kucukemiroglu, O. 1992. Sourcing of Industrial Products: Regiocentric Orientation of Chinese Organizational Buyers. European Journal of Marketing, 26(5), 36-55.

King, A.W., Fowler, S.W. and Zeithaml, C.P. 2001. Managing organizational competencies for competitive advantage: The middle-management edge. The Academy of Management Executive, 15(2), 95-106.

Kotler, P. 2002. Marketing Management, Millenium Edition. Tenth Edition ed. New Jersey: Prentice-Hall, Inc.

Kotler, P., Armstrong, G. 2012. Principles of Marketing. edited by P.P.H. 14th ed, New Jersey.

Langerak, F., Hultink, E.J. and Robben, H.S.J. 2004. The Impact of Market Orientation, Product Advantage, and Launch Proficiency on New Product Performance and Organizational Performance. J. Prod. Innov. Manag., 21, 79-94.

Lascu, D.N., Manrai, L.A. and Manrai, A.K. 1996. Value differences between Polish and Romanian consumers: A caution against using a regiocentric marketing orientation in Eastern Europe. Journal of International Consumer Marketing, 8(3, 4), 145-167. 
Leonidou, L.C., Leonidou, C.N., Fotiadis, T.A. and Zeriti, A. 2013. Resources and capabilities as drivers of hotel environmental marketing strategy: Implications for competitive advantage and performance. Tourism Management, 35, 94-110.

Levy, O., Beechler, S, Taylor, S. and Boyacigiller, N.A. 2007. What we talk about when we talk about 'global mindset: Managerial cognition in multinational corporations. Journal of International Business Studies, 38, 231-258.

Li, L.X. 2000. An Analysis of Sources of Competitiveness and Performance of Chinese Manufacturers. International Journal of Operation and Production Management, 20(3), 299-315.

Li, T. and Calantone, R.J. 1998. The impact of market knowledge competence on new product advantage: Conceptualization and empirical examination. Journal of Marketing, 62(4), 13-29.

Li, Y.H. and Huang, J.W. 2012. Ambidexterity's mediating impact on product development proficiency and new product performance. Industrial Marketing Management, 41, 1125-1132.

Liu, C.M., Lin, K.W. and Huang, C.J. 2014. Effects of Product Development on Operating Performance in Textile Industry. Anthropologist, 17(1), 157-163.

Ma, H. 2004. Toward global competitive advantage: Creation, competition, cooperation, and co-option. Management Decision, 42(7/8), 907-924.

Makadok, R. 2001. Toward a synthesis of the resource-based and dynamic-capability views of rent creation. Strategic Management Journal, 22(5), 387-401.

Mayrhofer, W. and Brewster, C. 1996. In Praise of Ethnocentricity: Expatriate Policies in European Multinationals. The International Executive, 38, 6, 749.

McCarthy, E.J. 1975. Basic Marketing: A Managerial Approach. edited by I.R.D.I. Homewood, Inc.

Mone, S.D., Pop, M.D. and Paina, N.D.R. 2013. The "What" and "How" of Marketing Performance Management. Management and Marketing Challenges for the Knowledge Society, 8(1), 129-146.

Neill, S., McKee, D. and Rose, G.M. 2007. Developing the organization's sensemaking capability: precursor to an adaptive strategic marketing response. Industrial Marketing Management, 36(6), 31-44.

Newbert, S.L. 2008. Value, Rareness, Competitive Advantage, and Performance: A Conceptual-Level Empirical Investigation of the Resource-Based View of the Firm. Strategic Management Journal, 29, 745-768.

Perlmutter, H.V. 1969. The Tortuous Evolution of the Multinational Corporation. Columbia Journal of World Business, 4(1), 9-18.

Peteraf, M.A. 1993. The Cornerstones of Competitive Advantage: A Resource Based View. Strategic Management Journal, 14(3), 179-191.

Peteraf, M.A., Barney, J.B. 2003. Unraveling the resource-based tangle. Managerial and Decision Economics, 24, 309-323.

Porter, M.E. 1990. Competitive Advantage. New York, The Free Press.

Ramaswami, S.N., Srivastava, R.K., Bhargava, M. 2009. Market-based capabilities and financial performance of firms: insights into marketing's contribution to firm value. J. of the Acad. Mark. Sci., 37, 97-116.

Raphael, A. and Schoemaker, P.J. 1993. Strategic Asset and Organizational Rent. Strategic Management Journal, 14(1), 33.

Rundh, B. 2009. Packaging design: creating competitive advantage with product packaging. British Food Journal, 111(9), 988-1002. 
Russo, M.V., Fouts, P.A. 1997. A resource-based perspective on corporate environmental performance and profitability. Academy of Management Journal, 40, 534.

Salunke, S.S.T. and Srivastava, R.K. 2013. The impact of core product and core application on Product launch and its success in an Industrial Market. Basic Research Journal of Education Research and Review, 2(1), 16-21.

Seidenfuss, K.U., Kathawala, Y. and Dinnie, K. 2013. Regional and country ethnocentrism: broadening ASEAN origin perspectives. Asia Pacific Journal of Marketing and Logistics, 25(2), 298-320.

Silverman, S.N. 1995. An Historical Review and Modern Assessment of the Marketing Mix Concept. 7th Marketing History Conference Proceedings, VII, 25-35.

Slater, S.F. and Narver, L.C. 2000. The Positive Effect of a Market Orientation on Business Profitability: A Balanced Replication. Journal of Business Research, 48, 69-73.

Smith, J.B. and Barclay, D.W. 1999. Selling partner relationships: The role of interdependence and relative influence. The Journal of Personal Selling \& Sales Management, 19(4), 21-40.

Soltani, S., Ramazanpoor, E. and Eslamian, S. 2014. A Structural Equation Model of the Impact of New Product Development on Competitive Advantage. Engineering Management Research, 3(1), 99-108.

Song, X.M. and Parry, M.E. 1997. A cross-national comparative study of new product development processes: Japan and the United States. Journal of Marketing, 61(2), 1.

Sutikna, N. 2013. Imaging: An Overview of Communication Philosophy. Jenderal Soedirman University, 605-614.

Tooksoon, P. and Mohamad, O. 2010. Marketing Capability and Export Performance: the Moderating Effect of Export Dependence. The South East Asian Journal of Management, IV(1), 39-52.

Tregear, A., Kuznesof, S. and Moxey, A. 1998. Policy initiatives for regional foods: some insights from consumer research. Food Policy, 23(5), 383-394.

Ulrich, K.T., Eppinger, S.D. 2004. Product Design and Development edited by M.H. 3rd Edition.

Vesalainen, J., and Hakala, H. 2014. Strategic capability architecture: The role of network capability. Industrial Marketing Management, 43, 938-950.

Voss, G.B. and Voss, Z.G. 2000. Strategic Orientation and Firm Performance in an Artistic Environment. Journal of Marketing, 64, 67-83.

Weick, K.E., Sutcliffe, K.M. and Ketchen, D. 2005. Organizing and the Process of Sensemaking. Organization Science, 16(4), 409-451.

Wernefelt, B. 1984. A Resourced Based View of the Firm. Strategic Management Journal, 5, 171-180.

Yu, W., Ramanathan, R, and Nath, P. 2014. The impacts of marketing and operations capabilities on financial performance in the UK retail sector: A resource-based perspective. Industrial Marketing Management, 43, 25-31.

Zander, U. and Kogut, B. 1995. Knowledge and the Speed of the Transfer and Imitation of Organizational Capabilities: An Empirical Test. Organization Science, 6, 76-92.

Zhang, J., Wu, W.P. 2013. Social capital and new product development outcomes: The mediating role of sensing capability in Chinese high-tech firms. Journal of World Business, 48, 539-548. 